\title{
GRAMSCI E A EDUCAÇÃO DO EDUCADOR*
}

\author{
Marcos Del Roio*
}

\begin{abstract}
RESUMO: Com a fundação, em 1919, da revista L'Ordine Nuovo - que atravessou fases diversas -, Gramsci tratou de desenvolver uma teoria e uma prática política que tinham no problema de educação um elemento constitutivo essencial. Até a sua prisão, em 1926, Gramsci passou por três diferentes momentos de elaboração dessa questão. Um primeiro momento no qual ele dá prioridade à cisão, ao antagonismo e à auto-atividade dos trabalhadores diante do capital, no próprio cerne do processo produtivo capitalista. Educação, então, confunde-se com auto-educação. O momento que se segue é o da necessidade de se educar o Partido Comunista, recém-fundado, particularmente a sua direção. $\mathrm{O}$ terceiro momento é pensado como necessidade de se educar o educador das massas, reflexão que aparece no seu papel de dirigente principal do Partido Comunista Italiano (PCI).
\end{abstract}

Palavras-chave: Educação. Cultura. Intelectuais. Antagonismo. Revistas.

\section{GRAMSCI AND THE EDUCATION OF THE EDUCATOR}

ABSTRACT: When he founded the journal L'Ordine Nuovo in 1919 - which went through several different phases -, Gramsci tried to develop a political practice and theory that focused on education as the core constitutive element. Before his imprisonment in 1926, Gramsci evolved through three different stages to frame this issue. He first prioritized scission, antagonism and workers' self-organization against capital within the very capitalist production process. Education thus overlapped self-education. The next stage cen-

* Este texto está fundamentado no livro Os prismas de Gramsci: a fórmula política da frente única (1919-1926). São Paulo: Xamã; IAP; FAPESP, 2005. O tema da relação entre intelectuais e massa ou educador e educando é ali tratado de maneira transversal.

** Doutor em Ciência Política e professor livre-docente da Faculdade de Filosofia e Ciências da Universidade Estadual Paulista (UnEsP, campus de Marília).E-mail: delroio@terra.com.br 
ters on the need to educate the newly-founded communist party, particularly its directors and organizers. The third stage started when Gramsci came to consider the importance of educating the mass educators, a development that can be seen in his role as the main ICP leader.

Key words: Education. Culture. Intellectuals. Antagonism. Magazines.

Fundação da revista L'Ordine Nuovo e o movimento de fábrica: educação como auto-educação

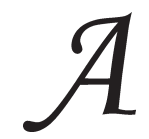

fundação da revista L'Ordine Nuovo aconteceu num cruzamento turbulento de águas que agitavam a Europa e a Itália ao fim da guerra imperialista de 1914-1918. Formados no ambiente de uma cultura humanista e livresca, na qual se destacava o influxo de Benedetto Croce, os fundadores da revista - com Gramsci à frente - percebiam a necessidade de agir no processo revolucionário que envolvia o continente. Essa nova conjuntura, inaugurada com a eclosão na Rússia da revolução socialista internacional, alterou, na prática, as condições de se pensar (e agir) sobre os problemas de organização da educação e da cultura. A revista emergia, contudo, com o objetivo de "promover o nascimento de grupos livremente constituídos no seio do movimento socialista e proletário para o estudo e a propaganda dos problemas da revolução comunista" (Gramsci, 1973, v. II, p. 19).

Até esse momento, a reflexão de Gramsci esteve voltada para a crítica do sistema escolar italiano, que enfatizava o ensino técnico destinado aos trabalhadores em busca de emprego ou, então, o ensino humanista destinado à pequena burguesia, cujo objetivo era o de compor os diversos escalōes da administração pública do Estado liberal-burguês. O desafio era o de pensar uma escola socialista unitária, que articulasse o ensino técnicocientífico ao saber humanista. Essa seria uma chave para que os trabalhadores pudessem perseguir a sua autonomia e desenvolver uma nova cultura, antagônica àquela da burguesia. A luta dos trabalhadores para garantir e aprofundar a cultura, para se apropriar do conhecimento, traria consigo o esforço e o empenho para assegurar a sua autonomia em relação aos intelectuais da classe dominante e ao seu poder despótico.

Esses intelectuais são elementos importantes na configuração de uma hierarquia de domínio sobre os trabalhadores, que só pode ser rom- 
pida a partir de uma reflexão própria dos trabalhadores sobre a cultura. Daí a ênfase de Gramsci sobre a proposta da criação de uma Associação de Cultura. Assim que,

(...) em Turim, dado o ambiente e a maturidade do proletariado, poderia e deveria surgir o primeiro núcleo de uma organização de cultura marcadamente socialista e de classe, que seria, junto ao partido e à Confederação do Trabalho, o terceiro órgão do movimento de reivindicação da classe trabalhadora italiana. (Gramsci, 1973, v. I, p. 143)

As classes dirigentes e os seus intelectuais são o inimigo a ser identificado. Contra eles devem ser criados uma nova cultura e um novo processo educativo. A influência de Georges Sorel ${ }^{1}$ é notável na defesa da autonomia do mundo operário e do antagonismo diante do capital, cuja subjetividade deve se manifestar de forma material. O "espírito de cisão" apresenta-se, desde logo, na recusa da escola do Estado e da igreja católica. Gramsci se debatia, no entanto, com a impotência das instituições da classe operária (o sindicato e o partido, antes de tudo) em realizar essa educação para a emancipação, em organizar a auto-educação dos trabalhadores, pois, para ele,

(...) o proletariado é menos complicado quanto pode parecer. Formou-se uma hierarquia espiritual e intelectual espontaneamente, e a educação intercambiável opera onde não pode chegar a atividade dos escritores e dos propagandistas. Nos círculos, nos feixes, nas conversações diante das oficinas se esmiúça e se propaga, tornada dúctil e plástica a todos os cérebros, a todas as culturas, a palavra da crítica socialista. (Gramsci, 1973, v. I, p. 189)

Mesmo depois da eclosão da Revolução Russa e da enorme efervescência cultural que tomou conta das fábricas e do espaço público, com a formação de inúmeros grupos de estudo e de pequenas publicações, a solução para o problema da educação autônoma do trabalho ainda não se deixara perceber. Tanto que L'Ordine Nuovo começou as suas atividades como uma resenha de cultura socialista, como um transmissor de certa cultura já acumulada, mas subalterna.

A guinada em direção à práxis ocorreu em fins de junho de 1919. Ficara claro para o grupo do L'Ordine Nuovo que a auto-educação dos trabalhadores, a educação para a liberdade, não dependia, ou dependia menos, do sindicato e do partido e muito mais dos próprios trabalhado- 
res. Inseridos no processo produtivo da riqueza social, os trabalhadores fabris eram já dotados de certo conhecimento profissional específico. O trabalho tecnicamente qualificado e produtivo deveria se vincular a um conhecimento mais amplo de cultura científica e humanista, não só para poder gerenciar o processo produtivo, mas a própria administração pública de um novo Estado operário e socialista. Assim é que os trabalhadores, no seu próprio processo de auto-educação, gerariam os seus intelectuais e seus educadores, educando assim o sindicato e o partido.

O organismo fundamental da democracia operária - já o demonstrara a revolução socialista na Rússia e na Hungria - era o conselho. $\mathrm{Na}$ Itália, em Turim, o conselho de operários e soldados de Petrogrado poderia ser traduzido nas comissões internas das fábricas, que seriam não apenas a escola de direção e administração do processo fabril, mas também de educação político-cultural da classe operária, dotada de um "espírito de cisão". A grande vantagem da democracia operária de base e da instituição da comissão interna de fábrica era o seu essencial caráter público, em contraste com o sindicato e o partido, instituiçóes do Estado burguês, conformadas em caráter privado.

Nas páginas do L'Ordine Nuovo, em diversas ocasiōes, Gramsci sugere que a liberdade do trabalhador deveria ocorrer a partir do espaço da fábrica, local onde cumpre o seu papel universal de produtor da riqueza social. A conquista da liberdade deveria eclodir onde os grilhôes do capital se faziam sentir de maneira mais intensa. $O$ partido e o sindicato são associações voluntárias de caráter contratual, dispostos no direito burguês. Portanto, para Gramsci, a liberdade do homem encontra o seu fundamento no estilhaçar das amarras que prendem a sua atividade de produtor aos interesses do capital. Particularmente da sua atividade de produtor, dotado de conhecimento técnico capaz de controlar o processo produtivo na fábrica moderna.

A liberdade encontra-se na difusão do espaço público. Se o sindicato e o partido não se submeterem ao controle do espaço público, gerado pela atividade emancipadora dos trabalhadores - servindo como instituições também de caráter educativo -, podem sim se transformar em aparelhos burocráticos privados dentro da ordem do capital e agente da dominação burguesa Os intelectuais que uma classe social forma podem, a qualquer momento, se voltar contra ela mesma!

Mas, atenção! O movimento de auto-educação das massas, o predomínio do espaço público é característico de um momento revolucio- 
nário. $\mathrm{O}$ movimento dos conselhos que eclodia em Turim, no período entre 1919 e 1920, era uma frente da revolução socialista internacional. Difícil, senão impossível, imaginar o L'Ordine Nuovo como agente de organização e educação das massas operárias fora do contexto revolucionário. Em outra situação, é mais provável que continuasse sendo uma resenha de cultura socialista. A guinada na orientação editorial e política da revista foi ela mesma o produto da educação ministrada pela classe operária aos seus educadores $\mathrm{A}$ virtude destes foi a imediata assimilação da lição e o seu engajamento completo na tarefa autodesignada.

Em torno ao L'Ordine Nuovo formaram-se comissōes de cultura, guiadas pela idéia de um soviet de cultura proletária, cujos entusiastas foram, em grande medida, os jovens socialistas. Mas o núcleo essencial dessa atividade, visando à construção do trabalho livre associado, é o conselho de fábrica, pois é no processo produtivo mesmo que se encontra o fundamento do processo de auto-educação e de auto-emancipação do trabalho. Tanto o movimento de classe pode educar o educador que, diz Gramsci,

(...) até agora os comunistas italianos tatearam no escuro. As massas proletárias italianas, como todas as massas proletárias do mundo, compreenderam que a "máquina" da revolução é o sistema dos conselhos, compreenderam que o processo de desenvolvimento da revolução é assinalado pelo surgimento dos Conselhos, da coordenação e sistematização dos Conselhos: compreenderam que o processo de desenvolvimento da revolução é assinalado pelo fato de que as massas populares reconhecem no sistema de Conselhos o órgão de governo das massas dos homens e da produção industrial e agrícola e determinam com a sua indiferença, com essa sua passagem de psicologia política, a atrofia das formas políticas atuais, a morte histórica da democracia burguesa. (Gramsci, 1973, v. II, p. 73)

O conselho deve, então, ser a base e o fundamento do Estado operário e socialista, das suas instituições sociais. Assim, a escola no Estado de transição deve ser uma escola do trabalho que se emancipa, uma escola que constrói e organiza o trabalho livre associado. Nessa escola, a ação laboriosa e disciplinada articula-se ao conhecimento da técnica, da ciência e da vasta cultura humanista. O método e o princípio pedagógico fundamentam-se no processo produtivo fabril, coletivo e solidário.

A escola organizada pelo L'Ordine Nuovo começou a funcionar em fins de 1920, quando o movimento dos conselhos de fábrica começava já a declinar, vítima dos ataques convergentes do Estado, dos 
nascentes grupos fascistas e da indiferença criminosa dos reformistas do sindicato, a Confederação Geral do Trabalho (CGL), e do partido (Partido Socialista Italiano - PSI). A escola do trabalho do L'Ordine Nuovo não tinha a intenção de preparar os trabalhadores para um mundo a eles estranho. Pelo contrário, a idéia era a de reforçar o principio de solidariedade e de saberfazer que era próprio do seu cotidiano de produtores, de incorporar o aprendizado já adquirido no espaço público gerado pela greve, pelo comício, pelo debate $\mathrm{O}$ primeiro passo é, portanto, o de aceitar que o educador se deixe educar. $\mathrm{O}$ método, a disciplina e a solidariedade próprios do mundo da fábrica deveriam ser a base da escola do trabalho.

No entanto, o objetivo da escola do trabalho era o de educar o proletariado para a autogestão da produção e para a administração pública, entendida como autogoverno. Na escola do trabalho é que também seriam lapidados os intelectuais gerados pela própria classe operária, em condiçôes de criar uma nova cultura, distinta e contraposta à da intelectualidade burguesa e mesmo reformista. Logo, a escola do trabalho encontra o seu método e o seu fundamento na ação dos produtores, mas o seu objetivo é o de contribuir para a construção do homem comunista, do trabalhador livre associado. Para isso, é imprescindível o controle da produção e do instrumento de trabalho, o que implica conhecimento técnico e científico.

A derrota do movimento dos conselhos de fábrica, em 1920, trouxe como implicação o fim dessa fase do L'Ordine Nuovo e da experiência do grupo político que lhe dava alento. $\mathrm{O}$ momento revolucionário de 1919-1920 foi um rico experimento de auto-educação e de educação do educador por parte dos trabalhadores. A clausura do sindicato e do partido operário mostrou a insuficiência dessa ação política educativa. Tratava-se agora, consumada a derrota, de fazer frente à ofensiva do capital, sendo necessário, para isso, construir um novo instrumento político, que conduzisse os trabalhadores à resistência e lhes possibilitasse reorganizar suas forças para o eventual contra-ataque.

O sindicato e o partido operário tinham desempenhado fielmente o seu papel de instâncias privadas e contratuais dentro do Estado burguês. Haviam negociado com o patronato e com o Estado às expensas dos conselhos de fábrica; haviam atuado pela estabilização da ordem social e política; haviam saído em defesa da democracia-parlamentar e se oposto à democracia operária dos conselhos. Mas tiveram que pagar o seu preço, e alto. Em janeiro de 1921, o PSI sofreu a sua primeira cisão orgânica e que seria o início da fragmentação das instituiçóes sociais da 
classe operária no seu recuo diante do ataque concentrado do fascismo em ascensão. Surge o Partido Comunista da Itália, em 1921, já que havia a necessidade sentida pelo grupo de Gramsci, e já tardia, da fundação de um novo instrumento de luta pela defesa da autonomia operária.

\section{L'Ordine Nuovo e o Partido Comunista Italiano: a educação do educador}

Finda a época revolucionária - embora não fosse essa a leitura feita por quaisquer das vertentes que convergiram para a formação do PCI a apreensão dos ensinamentos emanados da espontaneidade operária se fazia muito mais difícil. A escola do trabalho associado passaria então por um processo profundo de desmantelamento, pois a ofensiva do capital, cujo instrumento era o fascismo, teria desdobramentos no próprio processo produtivo fabril. O "americanismo", que Gramsci entendia ser a escola da inventividade, da laboriosidade e da autodisciplina, foi absorvido pelo fascismo como rígida disciplina do processo de trabalho.

A derrota demonstrava, dentre tantas outras coisas, que a classe operária não se encontrava preparada para se fazer Estado: faltavam-lhe os quadros para a administração do processo produtivo e para a administração pública. Mas a classe trabalhadora, ainda que derrotada, contava com forças e quadros suficientes para se fazer Partido revolucionário, completando a cisão orgânica com os reformistas.

No entanto, um problema grave era também apresentado pela composição do novo Partido Comunista. A maioria dos seus aderentes era de seguidores do grupo político que se formara em torno do periódico napolitano Il Soviet, no qual prevalecia a orientação de Amadeo Bordiga, ${ }^{2}$ reforçada ainda por elementos que vinham de setores "maximalistas" do PSI. A formação cientificista e naturalista de Bordiga o predispunha a conceber a classe operária como um organismo em desenvolvimento, dotado de um órgão específico que concentraria a ciência da classe: o partido revolucionário. Esse órgão deveria organizar a classe e difundir o conhecimento científico.

Aí, não há lugar para a espontaneidade operária, como não há lugar para alianças sociais com outras camadas de trabalhadores de extração pré-capitalista, como os camponeses. Tanto que essa fração do movimento socialista tendia a ver com suspeita o movimento dos conselhos, 
nele identificando um viés "sindicalista-revolucionário". A revolução confunde-se com um processo de longo prazo, durante o qual a ação do capital proletariza amplas massas, enquanto o partido organiza e educa essas mesmas massas para a tomada do poder político e a construção de um novo Estado.

O trabalho do grupo do L'Ordine Nuovo seria agora o de educar o educador. Ao PCI deveria ser transmitida a lição apreendida da espontaneidade das massas, da experiência concreta dos conselhos de fábrica como embrião de um Estado operário. Dizia Gramsci, então, que "a constituição do Partido Comunista cria as condições para intensificar e aprofundar a nossa obra", pois "poderemos nos dedicar inteiramente ao trabalho positivo, à expansão do nosso programa de renovação, de organização, de re-despertar das consciências e das vontades". Destacava ainda "que o programa do nosso movimento não se preocupa com as maiorias, senão quando estas criam as condições para organizar, para educar, para difundir convicçôes, para coordenar vontades e açôes" (Gramsci, 1973, v. II, p. 172).

Ocupando as instalaçôes do Avanti! de Turim (o jornal do PSI), a partir de janeiro de 1921, L'Ordine Nuovo passa a ser diário. O trabalho agora é o de resistência frente à ofensiva do capital, que instrumentaliza o movimento fascista. O surgimento do PCI ocorre em meio a sérias dificuldades, pois, além da necessidade de se criar condiçôes para resistir ao avanço do fascismo - para o que era necessário compreendê-lo -, era preciso disputar a direção do movimento operário, conseguir o suporte da maioria da classe. Isso implicaria uma decidida ação educativa, uma educação política revolucionária de longo alcance. Mas estaria o partido educador suficientemente preparado ele mesmo para tal tarefa?

Gramsci e o grupo do L'Ordine Nuovo eram francamente minoritários no interior da nova formação política e os problemas eram demasiado grandes. Compreender e enfrentar o fascismo não era uma tarefa fácil, como fácil não era conseguir a maioria da derrotada classe operária. Ademais, o PSI mantinha vínculo estreito com a Internacional Comunista, que entendia promover uma fusão entre as duas organizaçôes, deixando de fora apenas a ala social-reformista. Com tantas ameaças e dificuldades pairando sobre o PCI, Gramsci preferiu se submeter à maioria do partido, que seguia a orientação de Bordiga, e enfatizar, ainda uma vez, o problema da cisão orgânica e político-cultural com os socialistas, 
em vez de abrir outro campo de luta, pelo controle e pela direção do partido. Esse trabalho seria mais lento, de mais longo alcance e sem muito alarido.

Um momento crucial para a formação teórica e intelectual de Gramsci começou quando foi enviado para a Rússia, em maio de 1922, antes da ascensão do fascismo ao governo do Estado. Gramsci teve, então, a oportunidade de observar os esforços do Estado operário na construção de uma escola do trabalho, de acompanhar debates sobre o "americanismo" e sobre a organização do processo de trabalho, segundo a experiência taylorista e fordista. Fundamental foi mesmo o encontro com o bolchevismo e com Lênin, considerando que a tradução da revolução socialista internacional para as condições da Itália havia sido feita mais pelas lentes da cultura antagonista da Europa ocidental. Gramsci voltava agora ao papel de educando, pois o impacto da obra de Lênin e de outros bolcheviques seria indelével a partir de então na sua obra teórico-prática. Mas seria a marca da criatividade e da crítica a principal lição assimilada.

Armando-se do instrumental teórico oferecido pelo bolchevismo, Gramsci percebeu a necessidade e amadureceu a perspectiva de abrir a luta pela condução do comunismo italiano, confrontando-se com a concepção teórica e política de Bordiga e também com a leitura de Ângelo Tasca $^{3}$ sobre o partido, a Internacional Comunista (IC) e o processo revolucionário. Ambas as perspectivas traziam aspectos de submissão à tradição socialista italiana, que deveriam ser superados e que poderiam ser sintetizados na concepção da relação entre intelectual e massa, do destaque entre as instâncias do ser e do movimento. Tanto Bordiga quanto Tasca, de forma diferente e com conclusões também diferentes, viam o intelectual como dissociado das massas e não percebiam como o educador pode e deve ser educado pelo educando. No fundo, o problema era de uma compreensão muito tosca da dialética.

Na prática política, Gramsci definiu a sua posição contrastando a investida de Bordiga e de Tasca. O primeiro favorável à formação de uma corrente de esquerda internacional que fosse contra a política de frente única, defendida pela IC, e também contra a fusão ou mesmo aliança com os socialistas; já o segundo, favorável à política de frente única que preconizava a aliança e a fusão com os socialistas. Gramsci, por sua vez, defendeu a manutenção dos laços com o grupo dirigente da IC, a incorporação ao PCI de elementos da esquerda socialista, sendo favorável à política 
de frente única, mas não com os socialistas, pois tanto o PSI quanto a CG eram, para ele, instituições assimiladas ao Estado burguês. Entendia ainda que a fórmula política da frente única deveria unificar a classe operária e selar uma aliança fundamental com o proletariado agrícola e o campesinato, para o que os intelectuais meridionalistas liberais deveriam contribuir decididamente.

No entanto, não se tratava, para Gramsci, de fazer predominar o antigo grupo do L'Ordine Nuovo no PCI, mas sim de construir um novo grupo dirigente, capaz de criar um "sistema educativo" novo e adequado às condições. Esse grupo deveria educar a si mesmo, na medida em que ele próprio se formava, superando o espírito de seita e, ao mesmo tempo, deveria ser capaz de assimilar a melhor expressão de cultura e ação política geradas no seio da própria classe trabalhadora. Além de se autoeducar, o educador deveria continuar sendo educado pelo educando. Assim, e somente assim, os riscos regressivos, do ponto de vista cultural e político, presentes nas diferentes posições de Bordiga e de Tasca, poderiam ser superados numa nova síntese teórica.

A posição política defendida por Gramsci foi beneficiada pela repressão fascista, que afetou dramaticamente o grupo dirigente original do PCI, e pela insistência de Bordiga em se opor às diretrizes da IC, entregando a direção partidária à fração de Tasca. Além disso, a derrota dos "fusionistas" do PSI acabou empurrando apenas a ala mais à esquerda dessa agremiação para o seio do PCI. Ainda em Moscou, em 1923, foi tomada a decisão de criar um órgão de massa, que levaria o título de L'Unità, voltado para a difusão da política de frente única e da palavra de ordem do governo operário-camponês.

O jornal, assim como toda a política do partido, segundo Gramsci, deveria "dar importância especialmente à questão meridional, isto é, à questão na qual o problema das relações entre operários e camponeses se põe não só como um problema de relação de classe, mas também e especialmente como um problema territorial, isto é, como um dos aspectos da questão nacional” (Gramsci, 1992, p. 130).

\section{A educação do educador das massas: o partido revolucionário}

Foi em Viena, para onde fora mandado pela direção da IC, em 1923, que Gramsci amadureceu as suas idéias das relaçôes educativas 
entre intelectuais e massa, que deveriam se consubstanciar em um progresso intelectual de massas, sendo um substrato imprescindível para se conceber uma idéia de partido revolucionário e de revolução socialista. Além do L'Unità, Gramsci resolveu dar vida a uma revista quinzenal que retomasse o título de L'Ordine Nuovo e que seria, assim, uma terceira série. Essa publicação estaria, em alguma medida, voltada "para a educação dos companheiros mais qualificados e responsáveis para determinar um movimento de simpatia pelo nosso partido em certos ambientes de intelectuais” (Gramsci, 1992, p. 147).

Gramsci sugeriu apresentar "L'Ordine Nuovo como uma revista que se propõe a suscitar nas massas de operários e camponeses uma vanguarda revolucionária, capaz de criar o Estado dos conselhos de operários e camponeses e de fundar as condições para o advento e a estabilidade da sociedade comunista" (idem, ibid., p. 169).

Além do L'Unità, um jornal voltado para as massas, e da L'Ordine Nuovo, uma revista voltada para educar e selecionar a vanguarda operária, Gramsci sugeriu também a elaboração de um anuário da classe operária e a publicação de uma biblioteca de textos fundamentais, que seriam o instrumento para uma escola de partido. Essa escola, devido às condições difíceis impostas pela reação fascista, poderia assumir o formato de escola por correspondência.

Gramsci pensou ainda na criação de uma outra revista, com um perfil mais estritamente intelectual, que poderia ter o nome de Crítica Proletária e cujo objetivo seria o de estabelecer uma crítica à cultura dominante. Como esse amplo projeto demandava organização e recursos, Gramsci conseguiu apenas parcialmente alcançar os objetivos propostos.

No contexto político de disputa dentro do PCI, Gramsci considerava que o L'Ordine Nuovo teria um papel decisivo a cumprir. Deveria não só demonstrar a necessidade do governo operário e camponês nas condições nacionais, como também indicar os problemas ligados à organização da fábrica. A sustentação da revista deveria estar estreitamente vinculada ao levantamento de recursos para colocar em ação "um curso por correspondência de organizadores e propagandistas do partido". Na concepção de Gramsci (1978, p. 23), "o curso por correspondência deve se transformar na primeira fase de um movimento pela criação de pequenas escolas de partido, atuando para criar organizadores e propagandistas bolcheviques, não maximalistas, que tenham cérebro, além dos pulmões e garganta”. 
Gramsci evitava qualquer manifestação utópica e percebia que o primeiro passo a ser dado para a emancipação espiritual dos trabalhadores seria a formação dessas pequenas escolas. Os militantes mais velhos e experientes deveriam passar as suas experiências para pequenos grupos de cerca de uma dezena de novos militantes. Quadros políticos bem formados eram indispensáveis para se conseguir guiar a maioria da classe operária e para desorganizar o PSI - entendido sempre como instituição incorporada à ordem burguesa.

O material pedagógico da escola de partido deveria ser composto por opúsculos tratando das questôes elementares do marxismo, a explicação da necessidade do governo operário-camponês, a partir das condiçôes concretas da Itália, e um manual do propagandista contendo as informações sobre a realidade econômica e política da Itália. A idéia era ainda publicar uma edição do Manifesto Comunista, além de passagens de outras obras de Marx e Engels.

Esse projeto de educação concomitante da vanguarda operária e das massas começou a ser empreendido tão logo Gramsci retornou à Itália, em 1924, como deputado e principal dirigente do PCI. O jornal e a revista tiveram um sucesso significativo, sempre considerando as imensas dificuldades postas pela repressão fascista. A escola tomou mais tempo para ser posta em andamento, mas não resta dúvida de que seria um elemento a mais para preparar a militância para os debates do III Congresso do PCI, que seria realizado no inicio de 1926.

Gramsci nota com precisão que experiências de escola proletária nunca tiveram sucesso ou saíram de iniciativas isoladas de poucos que não conseguiram "combater e superar a aridez e infecundidade dos restritos movimentos 'culturais' burgueses". E isso por conta da "ausência de vínculos entre as 'escolas' projetadas ou iniciadas com um movimento de caráter objetivo" (Gramsci, 1978, p. 49).

Pelo contrário, o relativo sucesso da escola do L'Ordine Nuovo, em 1920, pode ser explicado pelo vínculo existente entre movimento e processo educativo, cuja implicação mais forte é a possibilidade do educador ser educado pelo movimento, um movimento conjunto de auto-educação das massas e de progresso intelectual coletivo. O limite daquela experiência foi o envolvimento de poucos e não de todo o movimento e de um partido, o que debilitou a capacidade de elaboração teórica coletiva. 
O novo empreendimento de Gramsci em organizar uma escola para militantes do proletariado, a partir de 1924, confrontou-se com a iniciativa do fascismo, recém-empossado no poder, no campo da reforma da educação e da escola. A reforma Gentile (1922) acentuava e explicitava a dualidade do sistema educativo italiano, ao reservar um ramo clássico-humanista para as classes dirigentes - ao qual estaria vedado o acesso para "os débeis e os incapazes" - e um outro ramo de base profissionalizante, voltado para as massas, que colimava na especialização precoce da força de trabalho.

O desafio cultural e educativo que Gramsci se propunha a enfrentar era enorme, mas só poderia ser efetivamente resolvido quando a classe operária formasse os seus próprios intelectuais. O desafio se via acrescido, no contexto de ascensão do fascismo, pelo fato de não haver um movimento operário com condiçóes favoráveis para criar e desenvolver suas próprias instituições.

Em oposição à concepção burguesa de educação, Gramsci indicava que "nem um 'estudo objetivo', nem uma 'cultura desinteressada' pode ter lugar nas nossas filas (...)”. Dizia, ainda, referindo-se ao partido:

(...) somos uma organização de luta, e nas nossas filas se estuda para acrescentar, para afinar a capacidade de luta de cada um e de toda a organização, para compreender melhor quais são as posições do inimigo e as nossas, para poder adequar melhor as nossas ações de cada dia. Estudo e cultura não são para nós outra coisa que a consciência teórica dos nossos fins imediatos e supremos e do modo que podemos conseguir traduzi-los em ação. (Gramsci, 1978, p. 49-50)

Gramsci considerava de suma importância educar um grupo dirigente da classe operária nas condições de refluxo e de terror em que se vivia, pois esse grupo deveria estar preparado para dirigir o processo revolucionário. Tal grupo dirigente era também importante para administrar o Estado proletário e para educar massas crescentes de trabalhadores no sentido da emancipação, sem que estas voltassem a ficar sob a influência das velhas ideologias. Assim, a tarefa de preparação para dirigir a revolução e administrar o Estado proletário deveria ser enfrentada desde já. Um grupo dirigente capacitado era imprescindível também porque “a retomada do processo revolucionário e especialmente a sua vitória despejam grande número de novos elementos para as suas fileiras", quando surge o problema de "impedir que o núcleo central do partido seja 
submerso e desagregado pelo ímpeto da nova onda", que chega sem a devida preparação (idem, ibid., p. 52).

O drama concreto a ser enfrentado de imediato era o de educar a vanguarda em condições tremendamente desfavoráveis de ilegalidade e perseguição. Um aspecto agravante, considerado por Gramsci, era o fato de que o marxismo jamais tinha sido objeto de um estudo mais sério e sistemático por parte das direçôes do movimento operário, permanecendo na esfera de reflexão da intelectualidade burguesa, a não ser a notável exceção de Antonio Labriola. A solução prática, que pareceu ser a única possível naquelas circunstâncias, foi a de propor uma escola por correspondência.

O curso, enfim implantado a partir de abril de 1925, foi pensado para se desenvolver em três series de liçôes, a primeira das quais sobre a teoria do materialismo histórico, tendo por referência o livro de Bukhárin, o Tratado sobre o materialismo histórico. ${ }^{4}$ A segunda parte do curso seria centrada em temas de política geral, que passariam por noções de economia política, formação e desenvolvimento do capitalismo, história do movimento operário, a guerra e a crise capitalista, a Revolução Russa, a transição etc. A terceira parte seria dedicada às questóes próprias do PCI, como a doutrina, o programa e a organização revolucionária, de acordo com a orientação da Internacional Comunista. Como material de suporte e complemento, seriam publicados fascículos mensais sobre temas específicos, como a questão sindical e a questão camponesa, entre outras.

Uma primeira avaliação do curso indicou problemas na forma de exposição didática, que tendia a ser muito absoluta e enfática. $\mathrm{O}$ plano geral deveria ser mais restrito, com temas mais específicos e tratamento mais elementar. $\mathrm{O}$ risco, segundo Gramsci, era aquele de se transmitir aos alunos a idéia de que as noçóes aprendidas deveriam ser encaradas como verdades indiscutíveis e adquiridas definitivamente, em vez de algo "que deveria ser ainda elaborado, demonstrado, [que] deveria ser ainda objeto de exame e de discussão" (Gramsci, 1978, p. 58).

Muitos dos problemas apontados na avaliação tinham fundamentos nas condições de existência da própria classe operária e eram de difícil resolução, agravados pelo fato da escola funcionar por correspondência. Nesse tipo de escola, considerava Gramsci, não era possível levar na devida conta a diversidade dos alunos, em termos de idade, de origem, de formação anterior, de experiência social, o que obrigava a se partir de um abstrato tipo médio de aluno. O resultado é que as lições ganhavam 
um caráter mecânico e absoluto. Por isso mesmo, dizia Gramsci, "O melhor tipo de escola é, sem dúvida, a da escola falada, não o de escola por correspondência”. Na escola falada o professor pode visar ao objetivo de "fazer viver coletivamente a escola, de modo que ocorra um continuo desenvolvimento de cada um e que tal desenvolvimento seja contínuo e sistemático" (idem, ibid., p. 58).

Mas a educação precede a escola. A mais importante iniciativa é a da auto-educação, o autodidatismo, depois do que "a escola acelera a formação, é o sistema Taylor da educação, dá um método, ensina a estudar, habitua a uma disciplina intelectual, [mas] não pode substituir o espírito de iniciativa no campo do saber" (idem, ibid., p. 59).

A relação entre a escola e a experiência de vida, no entanto, é muito diferente conforme a classe social. Para os jovens da burguesia, por serem da classe dominante, a escola serve para treiná-los, para adequá-los, para se portarem e se verem como dominantes. A escola de classe da burguesia, que na Itália se expressava na seqüência ginásio-liceu-universidade, deve agir para formar a classe dirigente e o seu eventual fracasso é o fracasso dessa classe. Além disso, "para a classe operária, o Estado burguês organizou um particular tipo de escola: a escola popular e a escola profissional, voltadas a manter a divisão de classe, a fazer com que o filho de operário seja também ele um operário" (idem, ibid., p. 60).

O conhecimento científico, nas condiçôes instauradas sob o domínio burguês, está fora do alcance da classe operária, que fica submetida a um conhecimento fragmentado, derivado da prática profissional e a uma baixa auto-estima, própria dos dominados. Daí a necessidade dessa classe criar instituições próprias que organizem o conhecimento. Pode ser o sindicato ou o partido, ou uma escola propriamente dita, mas essa sempre "completa e esclarece as experiências concretas da vida vivida, dá uma direção, habitua a generalizar, a raciocinar melhor e rapidamente" (idem, ibid., p. 59).

Percebe-se, então, a enormidade do desafio para que se chegue a uma escola orgânica do trabalho, a uma escola unitária. A escola por correspondência para a educação da vanguarda operária não podia ser mais do que uma pequena semente de duvidosa germinação, cujo escopo era o de criar uma intelectualidade orgânica da classe operária.

A urgência maior para o desenho estratégico que Gramsci vinha elaborando era a de forjar uma sólida maioria no III Congresso do PCI, 
que se avizinhava. A escola por correspondência e as viagens de Gramsci para acompanhar os encontros partidários locais e regionais fizeram o seu efeito. Com o respaldo de uma grande maioria partidária, Gramsci e seus mais próximos colaboradores conseguem delinear uma estratégia para a revolução socialista na Itália, cujo ponto de arranque seria a unificação da classe operária e a aliança com o proletariado agrícola e com o campesinato pobre. Essa frente única das classes subalternas deveria produzir uma nova sociabilidade e uma nova cultura para se opor ao fascismo e ao liberalismo, de modo que a revolução antifascista fosse também uma revolução anticapitalista.

É nesse contexto que aparece, com toda a clareza, a necessidade de se educar e de se preparar o educador das massas, o partido revolucionário. A fim de estruturar a frente única, o partido deveria subtrair a base de influência dos socialistas na classe operária, desorganizando essa agremiação, o que demandaria capacidade orgânica na fábrica e no sindicato, isto é, capacidade intelectual e organizativa. A visão mecânica e positivista da burguesia, que impregnava o operariado, deveria ser batida. Para isso, seria necessária uma massa crescente de intelectuais orgânicos da classe operária, que tivesse o mais estreito vínculo com o processo de trabalho, pois lhe caberia conduzir o necessário controle social da produção, fundamento do objetivo revolucionário.

Além disso, era necessário selar a aliança com o campesinato, submetido ao tacão do latifúndio e da ideologia religiosa. A influência do Partido Popular (católico) e de outras agremiaçôes políticas vinha perdendo fôlego no sul do país, devido à consolidação do fascismo e do seu vínculo com a igreja católica. Era esse o problema que Gramsci vinha analisando nos meses que precederam a sua prisão.

No esboço que ficou conhecido como Alguns temas da questão meridional, ${ }^{5}$ Gramsci procurou identificar as formas e os instrumentos que mantinham os trabalhadores rurais sob aquela brutal submissão. A sólida sobrevivência de características feudais na Itália obrigou Gramsci a deslocar sua análise para a dimensão político-estatal e intelectual. Ele percebe que há uma autonomia relativa dos grandes intelectuais, que transcendem as fronteiras nacionais com o seu cosmopolitismo, cujo exemplo maior é Benedetto Croce. O fundamental, no entanto, é a existência de uma massa de pequenos intelectuais vinculados à burguesia rural e que compõe a burocracia estatal e o clero. É esse tipo de intelectual 
“que, também localmente, na vila e no burgo rural, exercita a função de intermediário entre o camponês e a administração em geral” (Gramsci, 1996, p. 175).

Para alcançar o objetivo da frente única da classe operária com o campesinato, a estratégia definida por Gramsci indicava a necessidade de uma inserção importante do partido revolucionário entre o proletariado agrícola e o campesinato, com a elevação cultural e incorporação a suas fileiras de militantes oriundos dessas frações sociais. Contudo, o mais importante, pelo menos em um momento inicial, era selar a aliança com os intelectuais meridionais liberal-revolucionários, que percebiam e reconheciam a importância nacional da classe operária e o papel que poderia desempenhar na luta pela emancipação das massas camponesas do sul.

\section{Considerações finais}

$\mathrm{Na}$ reflexão de Gramsci, a dialética entre o educando e o educador resguarda sempre o trabalho como fundamento da sociabilidade emancipada do homem, ganha sempre novas dimensões. Gramsci parte da escola do trabalho, na qual prevalece a auto-educação, mas que possibilita um largo aprendizado a quem se pretende educador, pois é aqui na auto-educação do trabalho - que se localiza a via para a emancipação humana. De qualquer modo, essa via já é a revolução em ato.

Quando a revolução se viu derrotada, foi preciso encontrar meios para a educação da vanguarda operária, particularmente no caso em que essa vanguarda se revestia de uma discutível concepção de processo revolucionário. Nesse momento, a disposição em aprender com a experiência dos bolcheviques foi muito pertinente.

Uma vez forjada essa vanguarda, ainda que de maneira muito embrionária, a dialética do educador e das massas, tendo em vista um progresso intelectual, não só enriquece como organiza a classe operária, que produz os seus intelectuais. Essa vanguarda, esses intelectuais devem se capacitar para gerir o processo produtivo e para administrar o Estado operário, mas têm também que se relacionar com aliados, sem os quais não se compóe a frente única das classes subalternas na luta antifascista e anticapitalista e não se cria uma nova cultura de organização do trabalho livre associado.

Recebido em fevereiro de 2006 e aprovado em abril de 2006. 


\section{Notas}

1. Georges Sorel (1847-1922) foi um dos mais importantes teóricos do sindicalismo revolucionário na França do início do século XX. No Brasil, esse movimento ficou mais conhecido como anarco-sindicalismo.

2. Il Soviet, fundado em 1918 por Amadeo Bordiga (1889-1970), se tornaria o centro vital da polêmica contra os reformistas e em torno do jornal se reuniriam, posteriormente, os defensores da criação de um novo partido na Itália. Desde 1918, Bordiga apoiava a Revolução Russa e foi o principal fundador do Partido Comunista na Itália. Dele foi expulso em 1930, por divergências teórico-políticas com a nova maioria que se formara.

3. Ângelo Tasca (1892-1960) foi um dos fundadores da revista L'Ordine Nuovo, mas desde logo apresentou uma visão diversificada dos objetivos da publicação. Contribuiu também para fundar o PCI e se destacou depois como uma das lideranças críticas tanto de Bordiga quanto de Gramsci, sendo identificado como pertencente a uma vertente de direita dentro do movimento comunista. Foi expulso do PCI em 1930.

4. Esse livro de Nicolai Bukharin (1888-1938), publicado na Rússia em 1921, foi escrito com o intuito de difundir o marxismo. Obteve enorme sucesso e foi traduzido em diversas línguas. No entanto, sofreu críticas duras de Lukács e, mais tarde, nos Cadernos do cárcere, também de Gramsci, que apontava a visão mecanicista exposta pelo autor naquele trabalho. Uma edição do livro do autor em português é: Bukharin, N. Tratado de materialismo histórico. Rio de Janeiro: Laemmert, 1970.

5. O manuscrito de Gramsci foi interrompido quando ele foi preso em novembro de 1926. Recolhido por Camila Ravera, dirigente de ponta do PCI, foi publicado em 1930, em Paris.

\section{Referências bibliográficas}

BUKHARIN, N. Tratado de materialismo histórico. Rio de Janeiro: Laemmert, 1970.

DEL ROIO, M. Os prismas de Gramsci: a fórmula política da frente única (1919-1926). São Paulo: Xamã; IAP, 2005.

GRAMSCI, A. Scritti politici. Roma: Riuniti, 1973. 3v.

GRAMSCI, A. La costruzione del partito comunista (1921-1926). Turim: Einaudi, 1978.

GRAMSCI, A. Lettere (1908-1926). Turim: Einaudi, 1992.

GRAMSCI, A. Disgregazione sociale e rivoluzione. Napoli: Liguori, 1996. 